\title{
Paleopharmacology and Pollen: Theory, Method, and Application
}

\author{
Sérgio Augusto de Miranda Chaves $/{ }^{+}$, Karl J Reinhard*
}

Laboratório de Ecologia, Escola Nacional de Saúde Pública-Fiocruz , Rua Leopoldo Bulhões 1480, 21041-210 Rio de Janeiro, RJ, Brasil *School of Natural Resource Sciences, University of Nebraska, Lincoln, NE, USA

Parasitism was a universal human condition. Because of this, people developed herbal medicines to treat parasites as part of their pharmacopoeias. We propose that it is possible to recover evidence of medicinal plants from archaeological sites and link their use to specific health conditions. This is a multidisciplinary approach that must involve at least paleoethnobotanists, archaeoparasitologists, paleopathologists, and pharmacologists.

Key words: paleopharmacology - palynology - Piauí - Brazil

This volume demonstrates that parasitic disease was a problem for human populations all over the world and at all time periods. It is very probable that human populations would have developed treatments of the symptoms of parasitic disease and remedies to eliminate the parasites from their bodies. This is one focus of the field of "paleopharmacology" (Holloway 1983, Reinhard et al. 1991, Reinhard 1998a). Already, this fledgling field has demonstrated that anthelminthics and treatments for symptoms were a part of the prehistoric pharmacopoeia. We are taking the opportunity here to summarize the current findings of ancient parasite therapies, present a case example from Piauí, Brazil, and to suggest a methodology to be applied in the future.

\section{PREHISTORIC PHARMACOPOEIAS IN THE AMERICAS}

Much is known about the Aztec pharmacopoeia. The Spanish were impressed by the Aztec medicinal plant knowledge and had this knowledge documented. Three documents survived: Primeros Memoriales, Codex Matritense, and the larger Florentine Codex. Ortiz De Montellano (1975) analyzed the Aztec pharmacopoeia and discovered the active ingredients for many medicinal plants, such as Chenopodium species used as a treatment for parasite infection. To look for evidence of earlier use of Chenopodium, coprolites were analyzed. Riley (1993) reviewed the archaeological evidence of this anthelminthic. Historically, five North American tribes were documented as using various species of Chenopodium as a vermifuge: the Cherokee, Rappahannock, Houma, Koasait, and Natchez. He then reviewed Reinhard et al.'s (1985) coprolite studies which suggested that some species of Chenopodium served as an Archaic Period prophylaxis for parasite infection. This was an inadvertent benefit of having many species of Chenopodium in the diet. Later, among Anasazi agriculturalists, there is coprolite evidence of the use of $C$. graveolens and $C$. botrys specifically as anthelminthics. Riley (1993) suggests that

${ }^{+}$Corresponding author. Fax: +55-21-2598.2670. E-mail: smiranda@ensp.fiocruz.br

Received 26 August 2002

Accepted 25 November 2002 in Salts and Mammoth Caves, Kentucky ancient hookworm and Ascaris lumbricoides infection resulted in the use of Chenopodium species to cure worm infection in the Southeast.

With regard to the general picture of Chenopodium use, Reinhard (1998a: 445) writes, "One of the significant aspects of these Chenopodium studies is the depiction of the development of pharmaceuticals in prehistory. Species of Chenopodium were used by ancient huntergatherers and agriculturalists primarily as a food source. As knowledge of various species of Chenopodium progressed, there came the recognition that certain species had a pharmacological value".

\section{POLLEN EVIDENCE OF MEDICINAL PLANTS}

Experimental studies show that pollen, once ingested, is not destroyed by the digestive process. Thus, pollen ingested as a tea results in the introduction of millions of pollen grains into the digestive tract. Pollen is often present in hundreds of thousands to millions of pollen grains per gram of coprolite.

Holloway (1983) was the first individual to look at pollen as evidence of medicinal plant use. Since then other researchers have followed his approach. Ephedra (Mormon tea) pollen was found in Mojave Desert, Chihuahua Desert, and Colorado Plateau hunter-gatherer coprolites (Reinhard et al. 1991, 2003, Sobolik \& Gerick 1993) ranging from tens of thousands to hundreds of thousands of grains per gram of coprolite. Although Ephedra is a remedy for many symptoms, it was used by American Indian cultures to remedy diarrhea (Moerman 1986). In the same studies, Larrea pollen was found. Larrea was also used to treat diarrhea (Holloway 1983). The research presented in this volume shows that parasites that could cause diarrhea occurred in this area (Gonçalves et al. this volume). Perhaps parasites were the cause of diarrhea treated with Larrea and Ephedra. However, Reinhard (1998a: 446) warns "Theoretically, it is unwise to assume that plants were used to treat the same illness in the past as those today. Therefore, it is also unwise to project contemporary uses of medicinal plants into the past".

The field of paleopharmacology is fraught with uncertainty. Identifying plant species and linking these species to possible medicinal use involves several stages of analysis. Each stage is dependent on accurate accomplishment of the previous stage. For example, if the iden- 
tification of a plant fragment is incorrect, then subsequent inferences about its medicinal role are incorrect. For these reasons, we present a methodology for assessing the medicinal implications of coprolite components.

\section{METHODOLOGY}

The recovery and analysis of any archaeological pharmacopoeia is a multidisciplinary endeavor that must address several questions (Reinhard 1998a). First, what were the diseases that afflicted the prehistoric study population? Second, what plants were present in the archaeological environment that had medicinal value? Third, what is the likelihood that these plants can be recovered? Fourth, what is the actual medical efficacy of the plant for the diseases suffered?

The first question must be answered by the analysis of human remains. Such remains include skeletons, coprolites, and mummies. With regard to skeletal populations, disease can be easily categorized into dental, degenerative, infectious, traumatic, and neoplastic. In most archaeological skeletal series, dental disease, degenerative disease, and trauma are common. Infectious disease frequency and neoplastic disease frequency is variable. Evidence of parasitic disease can be recovered from sediment associated with skeletons as demonstrated by Dittmar and Teegen in this volume. Evidence of plant consumption can be recovered from such sediments as demonstrated by Reinhard et al. (1992) and Berg (2002). Most recently, microfossils including starch granules and phytoliths have been discovered in dental calculus, thus adding to the range of botanical remains recoverable from skeletons (Reinhard et al. 2001). Therefore, skeletal analysis can potentially provide evidence of parasitism and plant consumption if modern field and laboratory methods are used.

Mummies are ideal for assessing the disease states of prehistoric populations. All categories of hard tissue disease seen in skeletons can be recovered through noninvasive analysis of mummies (Kiple et al. 2001). In addition, soft tissue pathology can be recovered (Aufderheide $\&$ Rodrigues-Martin 1998), including many types of disease that can be potentially treated by medicinal plants. Coprolites from the intestine can be recovered. A wide variety of plant remains can be recovered from coprolites (Reinhard 1998b, Reinhard \& Bryant 1992). Also, microresidues can be found within the intestine, even if no coprolites are present. In addition, chemical signals from hair can be used to trace use of certain medicinal plants such as coca by looking for the secondary metabolites of the medicinal compounds (Cartmell et al. 1991).

Once a profile of the diseases suffered by an ancient population is obtained, then a survey of the plants that were present in the archaeological environment can be made. Ortiz De Montellano (1975) provides an ideal model for this problem. He had the advantage of working with illustrated textual sources. But his first goal of identifying ancient medicinal plants is the same as that of prehistorians working without texts. The first question to be addressed is how different was the archaeological environment from the modern environment? If the ancient environment shared many or some features with the mod- ern environment, then a survey of modern plants is likely to provide a good idea of potential medicinal plants available in ancient times. If the environment is much different, then excavation and identification of ancient plant remains will be necessary to reconstruct the plant biodiversity in the archaeological environment.

The third question relates to the recovery potential of certain types of plant remains. In identifying an archaeological pharmacopoeia, one must consider the preservation potential of plant fragments and where these plant fragments are likely to occur. This is address by Pearsall (2000). One can sketch out a probability hierarchy of recovery for certain types of archaeological remains. To keep within a reasonable discussion length, we will discuss recovery potential for coprolites (Reinhard 1998b, Reinhard \& Bryant 1992) and skeletal sediments (Reinhard et al. 1992, Berg 2002).

Pollen grains and phytoliths are two types of microfossils that are essentially indestructible on the digestive tract of humans (Reinhard \& Bryant 1992). Phytoliths are the most durable plant remains. They are crystals of silica or calcium oxalate deposited in plant tissue. According to Piperno (1991) and Pearsall (2000), several families of monocotyledons and dycotyledons produce abundant quantities of phytoliths. The following families of monocotyledons produce quantities of phytoliths: Bromeliaceae, Cannaceae, Cyperaceae, Poaceae, Heliconiaceae, Marantaceae, Musaceae, Orchidaceae, Arecaceae and Zingiberaceae. The following dycotyledon families also produce quantities of phytoliths according to Piperno (1991): Acanthaceae, Annonaceae, Aristolochiaceae, Burseraceae, Cannabaceae, Chloranthaceae, Chrysobalanaceae, Asteraceae, Cucurbitaceae, Dilleniaceae, Euphorbiaceae, Loranthaceae, Magnoliaceae, Moraceae, Piperaceae, Rosaceae, Sterculiaceae, Ulmaceae, Urticaceae and Verbenaceae. Danielson and Reinhard (1998) documented the recovery of phytoliths of dietary species of plants from Texas. They found that up to $20 \%$ of the coprolite volume can be composed of phytoliths. This discovery is very relevant to areas were foliage is chewed for medicinal purposes. One area where this was and is done is in the Andean region of Peru and Chile. There, coca (Erythroxilum coca) was habitually chewed (Cartmell et al. 1991, Indriati \& Buikstra 2001). Phytoliths are present in the leaves of this plant and we have been searching for the phytoliths in mummies and coprolites from the Andean region.

Palynology, which is the study of pollen grains and spores, is one important area of research. Through palynology we can obtain important information about past plant communities, as well as about possible plant distribution in a given geological time. At archaeological excavations, pollen grains can be found inside the sediments; in the funeral urns, on the surface of objects manipulated by humans, or even on the surface and inside fossilized feces - coprolites. Pollen is very durable due to the inclusion of sporopollenin in structure of pollen walls (Reinhard $\&$ Bryant 1992). Sporopollenin is the most durable organic compound produced by plants. The interpretation of pollen data is complicated by aspects of pollen transport, preservation, and sampling. There is a long history 
of study of pollen grains from archaeological sediments and coprolites (Adams 1980, Bryant \& Holloway 1983, Hevly 1981, Reinhard et al. 1991, Reinhard \& Bryant 1992). More recently, the study of pollen grains from burial sediments has been pioneered (Reinhard et al. 1992) and widely applied (Berg 2002). Because pollen, like phytoliths, preserves in nearly all types of human remains, medicinal pollen is a particularly valuable source of information.

As discussed by Reinhard and Bryant (1992), seeds are very durable in coprolites. This relates to the success of recovering evidence of their prehistoric use as summarized by Riley (1993). Because the seeds are very durable and easily recognized even when fragmented, tracing Chenopodium use is relatively easy. However, in skeletal sediments seeds vary in their recovery potential (Reinhard et al. 1992). Seeds with thick and hard coats such as Chenopodium are recoverable. However, thin walled seeds decompose in open environments where skeletons preserve. Therefore, it may not be possible to recover a full range of seeds from sediments sampled from burials.

There are other types of remains that are much more fragile. Remains of vegetative parts of plants such as leaves and stems preserve only in fortunate circumstances. In coprolites and mummies, leaf fragments can be found. The epidermis of desert succulents preserves well and the cell patterns of even the tiniest leaf fragments can be preserved (Reinhard 1998b: 125). However, mastication severely fragments more delicate leaves of most plants and it is often difficult to identify the venation patterns needed for taxonomic identification of delicate herbs. Stems, including rhizomes, can be identified, but only with difficulty (Holden \& Nuñez 1993). Bark is occasionally found and can sometimes be identified to species, such as Fry's (1977) discovery dogwood (Cornus stolonifera) bark in a coprolite from Utah which produces an opiumlike, narcotic effect. However, in other cases, it is impossible to identify bark.

The goal in plant identification should be on the species level. Once the remains are identified to species, then the medical efficacy of that species can be identified. However, in some cases, genus level is still insightful. Identification to family level alone does not provide sufficient taxonomic resolution to address the potential medicinal use of plant residues. Beyond different preservation potentials, each type of botanical remain has a different identification potential. On a general level, seeds and fruits can be more often identified to species because seed morphology has been long studied and published (for example Martin \& Barkley 1961, Delorit 1970, Corner 1976). Thus, seeds and fruits, when encountered, can be very useful in identifying specific plants of medicinal importance. Herbal leaves have venation patterns that, if preserved, should allow for species identification.

Pollen is of variable taxonomic use. Some pollen types can be identified to species, especially arboreal, wind pollinated taxa. More frequently, pollen grains can be identified to genus or family level. For some taxa, genus level identification is useful as presented for willow and Ephedra species by Reinhard et al. (1991). Phytoliths are also variable with regard to species identification. Sometimes the structures that silicify, such as spiral thicken- ings in vascular tissue, are useless taxonomic indicators because they are found in many species in many families. However, other types of phytoliths take on specific structures identifiable to plant genera. To our knowledge, no one has developed an application of phytoliths to any archaeological pharmacopoeia. As we state above, we believe there is good potential for phytoliths as medicinal plant indicators because of their abundance in coprolites and high preservation potential.

Once the plant remains have been identified to a genus or species, one must determine if they had medicinal value. Did the plant species contain a physiologically active compound? Is it likely that the compound was efficacious given the prehistoric preparation methods and dosage?

Moerman (1986) compiled a list of known medicinal plants from the ethnographic literature for the Americas. This is a central reference for obtaining information about the potential use of a discovered plant species as a medicinal plant. However, efficacy is not demonstrated by use alone. Ortiz De Montellano (1975) found that a small proportion of Aztec medicinal plants did not have physiological active compounds. Therefore, people may have had faith in curative powers of some plants that was not warranted by the plant's curing ability. Only by testing the plants for active compounds can one be sure that the plants really had medicinal value. Currently there are several journals that publish articles on medicinal plants. Therefore, when a potential medicinal plant is found, the published literature may have information concerning any medicinal value. Alternatively, samples of the plant can be submitted for pharmaceutical analysis.

\section{POLLEN EVIDENCE OF AN ANCIENT BRAZILIAN PHAR- MACOPOEIA}

Given the success of pollen studies of coprolites in North America in identifying prehistoric medicinal plants, we applied pollen analysis to three coprolites from Brazil (Fig. 1). The coprolites come from the site of Pedra Furada located in the State of Piauí, Northeast Brazil ( $8^{\circ} 50^{\prime} 10^{\prime \prime} \mathrm{S}$ $\left.42^{\circ} 33^{\prime} 20^{\prime \prime} \mathrm{W}\right)$. The coprolite context date between $8450 \pm$ $80 \mathrm{BP}$ and $7230 \pm 80 \mathrm{BP}$ (Chaves \& Renault-Miskovsky 1996, Chaves 1996, 2000, 2001a, b).

In Brazil, we have been studying pollen preserved in coprolites (Fig. 2). According to Faegri and Iversen (1989), pollen grains cannot be destroyed by the digestive process, because their outer portion (sexine) is not altered by transition through the intestine. Coprolites, therefore, are fossils particularly rich in excellently preserved pollen grains. The pollen grains come from ingested food and inhaled air, as well as from the pollen rain contemporary with the deposit where the excrement is found. By analyzing the pollen in coprolites, palynology can thus provide information which, taken together with phytosociological surveys, makes it possible to reconstruct the plant environment where prehistoric humans lived. This can be related to geological time periods and specific locations. By studying the pollen and macro-remains contained in coprolites, it is possible to infer the food and medicinal uses of specific plants (Chaves 1996, 2000, 2001a, b, Chaves \& Renault-Miskovsky 1996). 


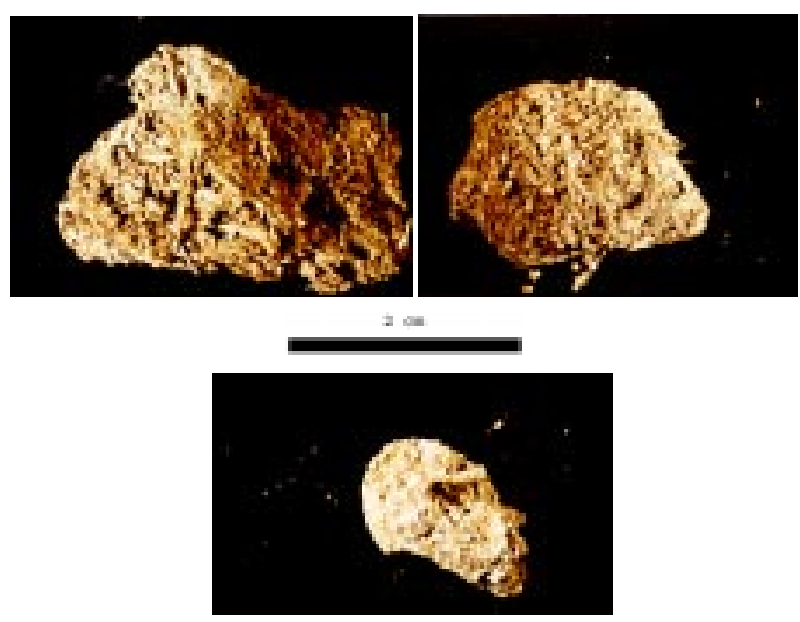

Fig. 1: human coprolites collected in a South American prehistoric site (Pedra Furada, Piauí) and dated of $7750 \pm 80 \mathrm{BP}$.

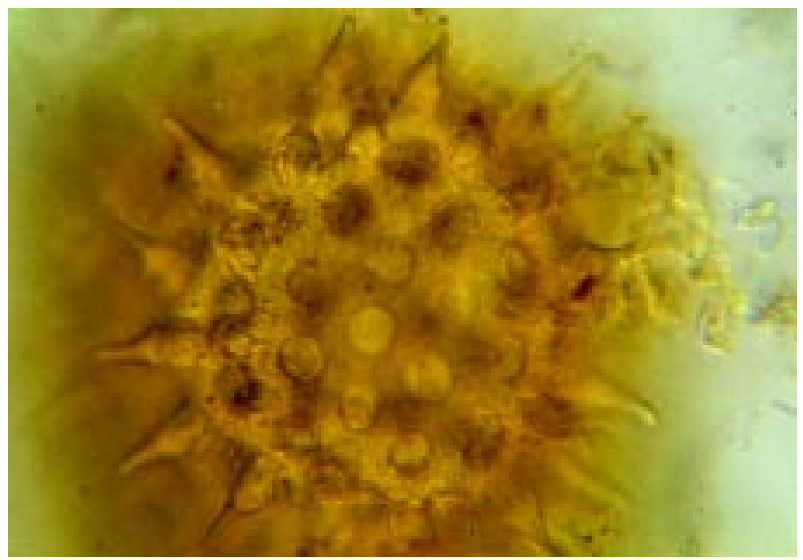

Fig. 2: pollen from a coprolite sample dated to $2,480 \pm 80 \mathrm{BP}$ collected in a South American prehistoric site Ipomoea batatas ("batata-doce") (1000X).

The prehistoric population in the area is known from a few skeletons and other human remains. Araújo et al. (2000) found human louse eggs in the region that demonstrates that the population had ectoparasites. Gonçalves et al. (this volume) summarizes the evidence of hookworm and whipworm infection in the population. Lessa and Guidon (2002) report dental pathology, spinal osteophytosis, and osteoarthritis from this region. Therefore, there was a spectrum of diseases in this population that would have required analgesics, anthelminthis, and treatments for lice.

After processing the coprolites in hydrochloric acid, potassium hydroxide, and flotation in zinc chloride, the pollen was extracted. Pollen grains from medicinal plants were recovered from the coprolites. Emperaire (1983) completed an ethnobotanical survey of the study region. She found that several plant taxa were used as folk remedies in the area by modern populations. We encountered some of the plants discussed by Emperaire. These medicinal plants included the following genera: Borreria, Sida, Anadenanthera macrocarpa, Bauhinia, Terminalia,
Caesalpinia, Cecropia, Croton, Mansoa, and Chenopodium.

Of these plant genera, some have uses that do not include treatment of intestinal parasites or the symptoms caused by them. Sida sp. ("malva-benta") can be used for treating wounds. Anadenanthera macrocarpa ("angico") is a treatment for tuberculosis and respiratory infections. The leaves of Cecropia sp. ("Embauba") are a analgesic. Croton sp. leaves ("marmeleiro, velame") are used for rhumatism, head-ache, influenza, and bronchitis. Mansoa hirsuta ("cipó-de-alho") is used for sore throats and diabetes. These plants, although interesting in that they reflect the medicinal needs of prehistoric people, are not relevant to intestinal parasite infections.

Other medicinal plant genera from the coprolites are relevant to parasitology. Some are vermifugic. The trunk of Bauhinia cheilanta ("miroro") is covered by bark which can be included in a vermifugic infusion. Of course, some species of Chenopodium, both seeds and foliage, have vermifugic properties.

Finally, some of the genera found are folk remedies for symptoms which can be caused by parasites. The leaves and fruits of Caesalpinea ferrea ("pau-ferro") are antidysenteric. Terminalia sp. ("maçarico") heals dysentery. Borreria sp. ("cabeça-de-velho") can be used as an infusion to facilitate digestion.

We encountered pharmacological data for one of these taxa. Bauhinia sp. contains active compounds including phytochemicals flavinoids, glycosides, heterosides, saponins, mineral salts, tannins, and beta-sitosterol. It is efficacious as a depurative, diuretic, and hypoglycemic (Silva et al. 2002). Pharmacological analysis does not confirm that this plant was a vermifuge.

The results presented here are tentative for several reasons. First, we do not know if the folk remedies for plants reported by Emperaire (1983) are really effective. Second, we do not know if the species in some genera are medicinal. For example, there are many species of Chenopodium that have the same pollen morphology. However, relatively few of these species are vermifuges. Thirdly, we can not assess whether the pollen in the coprolites represents an effective dose of the medicinal compound.

However, the number of potential medicinal plant taxa found in these three coprolites, and the spectrum of disease conditions evidence in the other prehistoric human remains in the region, highlight the possibility of identifying an archaeological pharmacopoeia for the Caatinga of Piauí. We now need to assess the efficacy of the taxa that we found and analyze more coprolites for seed, phytolith, leaf, and stem evidence of medicinal plants.

\section{REFERENCES}

Adams KR 1980. Pollen, Parched Seeds, and Prehistory: A Pilot Investigation of Prehistoric Plant Remains from Salmon Ruin, A Chacoan Ruin in Northwest New Mexico, Eastern New Mexico University Contributions to Anthropology 9, Eastern New Mexico University, Portales.

Araújo A, Ferreira LF, Guidon N, Maués da Serra Freire N, Reinhard KJ, Dittmar K 2000.Ten thousand years of head lice infection. Parasitol Today 16: 269. 
Aufderheide AC, Rodrigues-Martin C 1998. The Cambridge Encyclopedia of Human Paleopathology. Cambridge University Press, Cambridge.

Berg GE 2002. Last meals: recovering abdominal contents from skeletonized remains. J Archaeol Sci 29: 1349-1365.

Bryant Jr. VM, Holloway R 1983. The role of Palynology in Archaeology. In MB Schiffer, Advances in Archaeological Method and Theory 6, Academic Press, New York, p. 191223.

Cartmell LW, Aufderheide AC, Springfield A, Weems C, Arriaza B 1991. The frequency and antiquity of prehistoric coca leaf chewing practices in northern Chile: A radioimmunoassay study of a cocaine metabolite in human mummy hair. LAmer Antiq 2: 260-268.

Chaves SAM 1996. Metodologia utilizada para a extração de grãos de pólem de coprólitos humanos - Um estudo comparativo. Rev Mus Arqueol Etnol 6: 393-394.

Chaves SAM 2000. New paleovegetational and paleoethnobotanical perspectives on Brazil's Central Plateau: a palynological proposal. Rev Univ Guarulhos (Geociências V) Special Issue: 164 -167.

Chaves SAM 2001a. Análise palinológica de coprólitos préhistóricos holocênicos coletados na Toca do Boqueirão do sítio da Pedra Furada. Contribuições paleoetnológicas, paleoclimáticas e paleoambientais para a região sudeste do Piauí, Brasil. Rev Mus Arqueol Etnol USP 10: 103-120.

Chaves SAM 2001b. Pólens, paisagens e pré-história americana. Ciência Hoje 168: 57-59.

Chaves SAM, Renault-Miskovsky J 1996. Paléoethnologie, paléoenvironnement et paléoclimatologie au Piauí, Brésil: apport de l'étude pollinique de coprolithes humains recueills dans le gisement préhistorique Pléistocène de "Pedra Furada". C R Acad Sci Paris 322: 1053-1060.

Corner EJH 1976. The Seeds of Dicotyledons, Vols 1, 2. Cambridge University Press, New York.

Danielson DR, Reinhard KJ 1998. Human dental microwear caused by calcium oxalate phytoliths in prehistoric diet of the lower Pecos region, Texas. Amer J Phys Anthropol 107: 297-304.

Delorit RJ 1970. An Illustrated Taxonomy Manual of Weed Seeds, Agronomy Publications, River Falls, Wisconsin.

Emperaire L 1983. La Caatinga du Sud-est du Piauí (Brésil): Étude Ethnobotanique. Éditions Recherche sur les Civilisations, Paris (Mém. no. 21).

Faegri K, Iversen J 1989. Textbook of Pollen Analysis, 4th ed. (revised by K Faegri, PE Kaland, K Krzywinski), John Wiley \& Sons, Chichester.

Fry GF 1977. Analysis of Prehistoric Coprolites from Utah. Anthropological Papers 97, University of Utah Press, Salt Lake City.

Hevly RH 1981. Pollen production, transport and preservation: potentials and limitations in Archaeological Palynology. J Ethnol 1: 39-54.

Holden TG, Nuñez L 1993. Analysis of the gut contents of five well-reserved human bodies from Tarapacá, Northern Chile. J Archaeol Sci 20: 595-611.

Holloway RG 1983. Diet and medicinal plant usage of a late Archaic population from Culberson County, Texas. Bul Tex Archaeol Soc 54: 319-329.
Indriati E, Buikstra JE 2001. Coca chewing in Prehistoric Peru: dental evidence. Amer J Phys Anthropol 114: 242-257.

Kiple D, Meier DK, Okoye M, Reinhard KJ 2001. Three dimensional (3-D) reconstruction applied to mummy conservation and display. In E Williams, Human Remains: Conservation, Retrieval and Analysis, BAR International Series 934, p. 167-172.

Lessa A, Guidon N 2002. Osteobiographic analysis of skeleton I, Sítio Toca dos Coqueiros, Serra da Capivara National Park, Brazil, 11,060 BP: First results. Amer J Phys Anthropol 118: $99-110$

Martin AC, Barkley WD 1961. Seed Identification Manual. University of California Press, Berkeley,

Moerman D 1986. Medicinal Plants of Native Americans, 2 vols, Museum of Anthropology, University of Michigan, AnnArbor.

Ortiz De Montellano B 1975. Empirical Aztec medicine. Science 188: 215-220.

Pearsall DM 2000. Paleoethnobotany. A Handbook of Procedures. 2nd ed., Academic Press, San Diego.

Piperno DR 1991. The status of phytolith analysis in the American tropics. $J$ Wd Prehistory 5: 155-191.

Reinhard KJ 1998a'. Paleopharmacology. In L Ellis, Archaeological Method and Theory: An Encyclopedia, Garland Publishing, New York, p. 432-447.

Reinhard KJ 1998b. Coprolite analysis. In L Ellis, Archaeological Method and Theory: An Encyclopedia, Garland Publishing, New York, p. 124-132.

Reinhard KJ, Bryant Jr. VM 1992. Coprolite analysis: a biological perspective on prehistory. In MB Schiffer, Archaeological Method and Theory 4, University of Arizona Press, Tucson, p. 245-288.

Reinhard KJ, Danielson DR, Daniels M, Chaves SAM 2003. Multidisciplinary approach to coprolite analysis and implications for prehistoric and modern native American Health. In PR Geib, Archaeological Investigations at Bighorn Cave. Bureau of Reclammation, Phoenix, AZ.

Reinhard KJ, Geib PR, Callahan MM, Hevly RH 1992. Discovery of colon contents in a skeletonized burial: soil sampling for dietary remains. J Archaeol Sci 19: 697-705.

Reinhard KJ, Hamilton DL, Hevly RH 1991. Use of pollen concentration in paleopharmacology: coprolite evidence of medicinal plants. J Ethnobiol 11: 117-134.

Reinhard KJ, McGuffie M, Ambler JR 1985. Diet and parasitism at Dust Devil Cave. Amer Antiq 50: 819-824.

Reinhard KJ, Souza SMF, Rodrigues C, Kimmerle E, DorseyVinton S 2001. Microfossils in dental calculus: a new perspective on diet and dental disease. In E Williams, Human Remains: Conservation, Retrieval and Analysis, BAR International Series 934, p. 113-118.

Riley TJ 1993. Ascarids, American Indians, and the Modern World: parasites and the Prehistoric record of a pharmacological tradition. Perspect Biol Med 36: 369-375.

Silva KL da, Biavatti MW, Leite SN, Yunes RA, Delle Monache F, Cechinel Filho V. 2000. Phytochemical and pharmacognositc investigation of Bauhinia forficata Link (Leguminosae). Z Naturforsch 55: 478-80.

Sobolik KD, Gerick DJ 1992. Prehistoric medicinal plant usage: a case study from coprolites. J Ethnobiol 12: 203-211. 